\title{
Ionic Effects on Strain Differences in Hepatic Cytosolic Glucocorticoid Receptor Levels in Mice
}

\author{
KENNETH J. HARPER AND ROBERT P. ERICKSON \\ Department of Human Genetics, University of Michigan School of Medicine, \\ Ann Arbor, Michigan 48109
}

\begin{abstract}
Ionic conditions were varied during homogenization of adult livers and during incubation of hepatic cytosol with glucocorticoid, and the effects on the detection of differences between inbred strains of mice for receptor levels were studied. When homogenized directly in $0.01 \mathrm{M}$ Tris or homogenized in distilled water and then buffered to either $0.05 \mathrm{M}$ Tris or $0.01 \mathrm{M}$ potassium phosphate, A/J glucocorticoid receptor levels were greater than those of B10.A. However, when homogenized directly in $0.05 \mathrm{M}$ Tris or buffered to $0.05 \mathrm{M}$ potassium phosphate after homogenization in distilled water, A/J and B10.A had similar receptor levels. When buffered to $0.01 \mathrm{M}$ Tris after homogenization in distilled water, $\mathrm{A} / \mathrm{J}$ receptor levels were greater than those of $\mathrm{B} 10$.A but not significantly so. In Tris buffers, glucocorticoid receptor levels were higher when livers were homogenized directly in buffer than when liver homogenates were buffered after homogenization. This concentration effect is apparently due to the more rapid decay of glucocorticoid receptor in the lower molarity buffer. A reducing agent, thioglycerol, did not appear to affect either the rate of decay of the receptors or the measured level of receptor for B10.A and A/J. C57BL/6J receptor levels were measured in Tris buffers and had a similar relationship to $\mathrm{A} / \mathrm{J}$ as did B10.A.
\end{abstract}

A popular model for studies of cleft palate is glucocorticoid-induced cleft palate in mice (Fraser and Fainstat, '51). Inbred strains of mice differ significantly for susceptibility to glucocorticoid-induced cleft palate, and it has been suggested that genetic variation in amount of glucocorticoid receptor may be a part of the explanation for this variation. However, there has been considerable controversy about the direction and degree of difference among inbred mouse strains for amount of glucocorticoid receptor. Salomon and Pratt presented evidence that cultured, embryonic facial mesenchyme cells from a strain with high susceptibility to glucocorticoid-induced cleft palate, $\mathrm{A} / \mathrm{J}$, have about twice as many specific steroid receptors as do such cells from a low susceptibility strain, C57BL/6 (Salomon and Pratt, '76). They also found a correlation of sensitivity to steroidinduced cleft palate with amount of steroidspecific receptor in cultured facial mesenchyme cells among several inbred strains of mice (Salomon and Pratt, '79). Goldman et al. (77) provided data that this variation in the amount of steroid receptor was associated with H-2 genotype, but this conclusion was contested. We demonstrated that a difference be- tween $\mathrm{A} / \mathrm{J}$ and $\mathrm{C} 57 \mathrm{BL} / 6 \mathrm{~J}$ of similar direction and degree to that found in cultured facial mesenchyme cells could be detected for hepatic cytosolic receptors but that variation among alleles at the H-2 locus does not affect these receptor levels (Butley et al., '78). Francke and Gehring ('80) mapped the glucocorticoid receptor locus to chromosome 18, not chromosome 17, which carries the H-2 locus. Hackney ('80) detected a specific glucocorticoid receptor in mouse fetal heads but found higher levels in the $\mathrm{C} 57 \mathrm{BL} / 6 \mathrm{~J}$ than in the $\mathrm{A} / \mathrm{J}$ strain. Differences in the glucocorticoid used for the measurements were not responsible for these differences: triamcinolone acetonide (TA) was used with mouse livers and mouse fetal heads with quite opposite results. Since a large variety of factors including $\mathrm{Ca}^{++}$(Arányi and Náray, '80), molybdate (Nielsen et al., '77b), alkaline phos-

Abbreviations used: TA, triamcinolone acetonide; ATP, adenosine triphosphate; Dx, dexamethasone; Tris, tris (hydromethyl) aminomethane.

Received November 5, 1981; accepted June 23, 1982.

Address reprint requests to Robert P. Erickson, M.D., Department of Human Genetics, Box 015, University of Michigan Medical School 1137 E. Catherine Street, Ann Arbor, MI 48109. 
phatase (Nielsen et al., '77a), ATP (John and Moudgil, '79), pyridoxine (DiSorbo et al., '80), 5 '-deoxypyridoxal (O'Brien et al., '80), pyridoxal 5' -phosphate (Dolan et al., ' 80 ), and unidentified dialyzable factors (Sato et al., '80) are known to affect measurements of glucocorticoid receptors, we sought to determine some factors with an effect on measured levels of hepatic glucocorticoid receptors. Of several variables studied, varying ionic conditions were found to have the greatest effects. We have continued to use adult livers as our source of glucocorticoid receptors since 1) they provide sufficient material for biochemical characterization and 2) the strain difference found parallels that originally reported (Salomon and Pratt, '76) in cultured embryonic facial mesenchyme cells.

\section{MATERIALS AND METHODS Chemicals}

$\left[{ }^{3} \mathrm{H}\right]$ Triamcinolone acetonide ( $\left.45 \mathrm{Ci} / \mathrm{mmole}\right)$ was obtained from New England Nuclear Corporation. Thioglycerol, Dextran 60-90, neutralized activated charcoal, dexamethasone, Tris- $\mathrm{HCl}$, and Tris base were obtained from Sigma Chemical Corporation. Monobasic and dibasic potassium phosphate were obtained from Mallinckrodt. Mice were produced in our lab from stock obtained from Jackson Laboratory and were ten weeks or older when used.

\section{Cytosol preparation}

Livers from decapitated mice were rapidly chilled and chopped on dry ice and homogenized in a prechilled Teflon/glass homogenizer in a fivefold volume $(5 \mathrm{ml} / \mathrm{gm})$ of a chilled $\left[0^{\circ} \mathrm{C}\right]$ lysis solution. To test the effect of different salt concentrations in the same preparation, livers were homogenized in distilled water with 12 $\mathrm{mM}$ thioglycerol, and then individual aliquots were immediately brought to the appropriate salt concentration. For the other experiments, livers were homogenized directly in lysis buffers ( $\mathrm{pH} 7.35$ at $\left.0^{\circ} \mathrm{C}\right)$ with or without $12 \mathrm{mM}$ thioglycerol. Cytosol was immediately prepared from the crude homogenate by centrifugation at $43,000 \mathrm{~g}$ for 30 minutes at $4^{\circ} \mathrm{C} ; 0.4$ $\mathrm{ml}$ of cytosol was then incubated at $0^{\circ} \mathrm{C}$ for 18-24 hours with either $4 \times 10^{-8} \mathrm{M}\left[{ }^{3} \mathrm{H}\right]$-TA or TA with a 1,000 -fold excess of unlabelled dexamethasone $(\mathrm{Dx})$ in a final volume of 0.5 $\mathrm{ml}$.

\section{Charcoal dextran assay}

Receptor-bound steroid was separated from free steroid by mixing $0.1 \mathrm{ml}$ of cytosol-steroid incubation mixture with $0.15 \mathrm{ml}$ of charcoal suspension (1\% Norit-A charcoal and $0.2 \%$ Dextran 60-90) following the method of Miras and Harrison ('79). After overnight incubation in the lysis buffer at $4^{\circ} \mathrm{C}$, the charcoal-dextran particles were washed by centrifugation at $3,000 \mathrm{~g}$ for five minutes to remove ultrafine particles. The charcoal suspension was stirred continuously for use in the assay. The charcoal-cytosol mixture was incubated for $10 \mathrm{~min}$ utes at $0^{\circ} \mathrm{C}$, and the samples were then spun for 5 minutes in a Beckman Microfuge B. One tenth of a milliliter of the final supernatant was counted in $10 \mathrm{ml}$ of Instagel. The protein concentration of the cytosol was determined by the method of Lowry. Specific binding is expressed as moles of TA bound per $\mathrm{mg}$ of protein and was determined by subtracting nonspecific counts (TA and Dx) from total counts (TA only). Small variations in technique, and possibly seasonally changes cause some apparent differences in receptor levels between experiments, especially at low levels when nonspecific counts may be as much as $85 \%$ of total counts. Therefore, we did not pool data from experiments done at different times for the same experimental condition when variability was high (e.g., Fig. 1 and Table 1, distilled water homogenization).

\section{RESULTS \\ Effect of various buffers when homogenization was in water}

We sought to determine the optimal buffer conditions for studying strain differences in glucocorticoid levels of $\mathrm{A} / \mathrm{J}$ and $\mathrm{B} 10$.A livers. Some additional work was done with $\mathrm{C} 57 \mathrm{BL} /$ $10 \mathrm{~J}$ since their receptor levels are similar to those of B10.A (Butley et al., '78). These studies of the effect of buffering conditions on mouse hepatic glucocorticoid receptor levels are shown in Table 1 (distilled water homogenization), Figure 1 and Figure 2. To reduce experimental variation, two to four livers were homogenized in double distilled water with $12 \mathrm{mM}$ thioglycerol, and then individual aliquots were buffered at various concentrations of either Tris or potassium phosphate $\left(\mathrm{pH} 7.35\right.$ at $\left.0^{\circ} \mathrm{C}\right)$. An aliquot to which no buffer was added was often assayed as a reference point. When Tris buffer was added, A/J glucocorticoid receptor levels were significantly greater than those of C57BL 10J (Table 1) and B10.A (Table 1, first column of data, and Fig. 1) in $0.05 \mathrm{M}$. In $0.01 \mathrm{M}$ Tris, $\mathrm{A} / \mathrm{J}$ receptor levels were greater than those of the black strains but not always significantly (compare Table 1 and Fig. 1). When potassium 


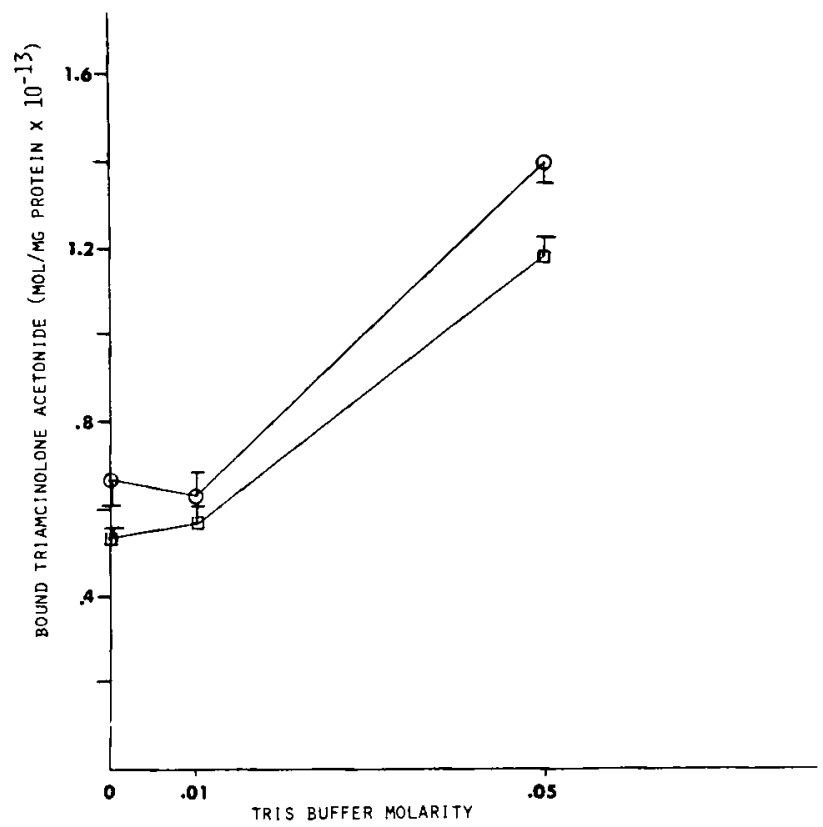

Fig. 1. Effect of Tris molarity $\left(\mathrm{pH} 7.35,0^{\circ} \mathrm{C}\right)$ on hepatic cytosol binding of triamcinolone acetonide in $\mathrm{A} / \mathrm{J}(\mathrm{O})$ and B10.A ( $\square$ ) homogenates buffered at the indicated levels of
Tris after homogenization in distilled water with $12 \mathrm{mM}$ thioglycerol (mean \pm S.E. for $9-12$ determinations).

TABLE 1. Effect of Tris molarity on hepatic cytosol binding of triamcinolone acetonide of $A / J, C 57 B L 10 J$, and B10A for livers homogenized either in the indicated Tris buffer or in distilled water with $12 \mathrm{mM}$ thioglycerol and subsequently buffered at the indicated Tris molarity ${ }^{1}$

\begin{tabular}{|c|c|c|c|c|}
\hline \multirow[b]{3}{*}{ Strain } & \multirow{3}{*}{$\begin{array}{c}\text { Tris } \\
\text { buffer }\end{array}$} & \multicolumn{3}{|c|}{ mole/mg protein $\times 10^{-13}$} \\
\hline & & \multirow{2}{*}{$\begin{array}{l}\text { Homogenized in distilled water } \\
\text { and then brought to } \\
\text { indicated molarity } \\
\text { of Tris buffer }\end{array}$} & \multicolumn{2}{|c|}{ Homogenized in Tris buffer } \\
\hline & & & Pooled livers $^{2}$ & Individual livers \\
\hline $\mathbf{A} / \mathbf{J}$ & $0.01 \mathrm{M}$ & $0.99 \pm .05 \quad(7)$ & $1.90 \pm .10(9)^{2}$ & $2.19 \pm .20(6)$ \\
\hline C57BL/10J & $0.01 \mathrm{M}$ & $0.47 \pm .05$ & & $1.20 \pm .17(7)$ \\
\hline B10.A & $0.01 \mathrm{M}$ & & $1.47 \pm .06(9)$ & \\
\hline $\mathrm{A} / \mathrm{J}$ & $0.05 \mathrm{M}$ & $1.61 \pm .04$ & $2.77 \pm .20(8)$ & $2.08 \pm .23(6)$ \\
\hline $\mathrm{C} 57 \mathrm{BL} / 10 \mathrm{~J}$ & $0.05 \mathrm{M}$ & $1.08 \pm .045(4)$ & & $1.90 \pm .18(6)$ \\
\hline B10.A & $0.05 \mathrm{M}$ & & $2.72 \pm .25(8)$ & \\
\hline
\end{tabular}

${ }^{1}$ Data pooled from livers homogenized both with or without $12 \mathrm{mM}$ monothioglycerol from $0 \mathrm{Hr}$ of Fig. 3 .

${ }^{2} \pm$ S.E.; Number of determinations is indicated in parentheses.

phosphate buffer was added, $\mathrm{A} / \mathrm{J}$ glucocorticoid receptor levels were significantly greater than those of B10.A at 0.005 , and $0.01 \mathrm{M}$ but not at $0.05 \mathrm{M}$ (Fig. 2). In all experiments, $\mathrm{A} / \mathrm{J}$ receptor levels were no more than twice as great as B10.A or C57BL/10J and receptor levels were greatest for each strain in $0.05 \mathrm{M}$ buffers (Fig. 2).
Effect of various buffers when homogenization was in the buffer

To determine if the relative strain differences at the various buffer concentrations found when homogenization was performed in distilled water could also be found when homogenization was performed directly in the buffer, 


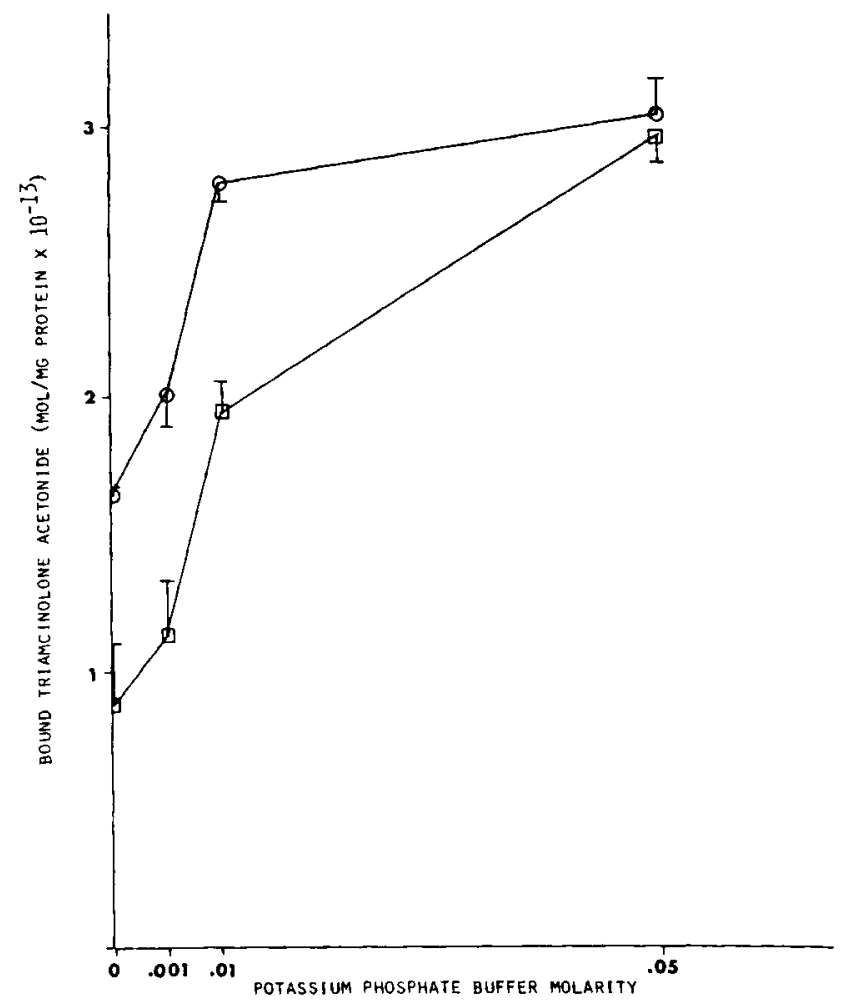

Fig. 2. Effect of potassium phosphate molarity (pH 7.35, $0^{\circ} \mathrm{C}$ ) on hepatic cytosol binding of triamcinolone acetonide in $A / J(O)$ and B10.A $(\square)$ homogenates buffered at the in- dicated levels of potassium phosphate after homogenization in distilled water with $12 \mathrm{mM}$ thioglycerol (mean \pm S.E. for four determinations). we carried out the experiments presented in Table 1 (individual livers, last column of data). The glucocorticoid receptor levels of individual $\mathrm{A} / \mathrm{J}$ and $\mathrm{C} 57 \mathrm{BL} / 10 \mathrm{~J}$ livers were measured after homogenization in either 0.01 or $0.05 \mathrm{M}$ Tris. Surprisingly, while AJ receptor levels were significantly greater than those of C57BL/10J at $0.01 \mathrm{M}$ Tris, there was no significant difference when homogenized in $0.05 \mathrm{M}$ Tris.

\section{Stability of glucocorticoid receptor in various buffers}

To further confirm the above finding and study the possible nature of the apparent effect of homogenization conditions, we studied the temporal decay of the hepatic glucocorticoid receptor levels in $\mathrm{A} / \mathrm{J}$ and B10.A in both 0.01 and $0.05 \mathrm{M}$ Tris (Fig. 3). Four livers were halved and one set of halves was homogenized in 0.01 $M$ Tris and the second set of halves was homogenized in $0.05 \mathrm{M}$ Tris. Approximately 45 minutes after homogenization cytosol was added to steroid at zero time (the usual time of addition). At this zero time, the $\mathbf{A} / \mathbf{J}$ glucocorticoid receptor level was significantly greater than that of B10.A at 0.01 but not at $0.05 \mathrm{M}$ Tris. This confirmed the results of experiments performed with individual livers (Table 1). For the

Fig. 3. Reduction in triamcinolone acetonide binding capacity of $\mathrm{A} / \mathrm{J}$ and $\mathrm{B} 10 . \mathrm{A}$ hepatic cytosols incubated at $0^{\circ} \mathrm{C}$ in $0.01 \mathrm{M}$ and $.05 \mathrm{M}$ Tris $\left(\mathrm{pH} \mathrm{3.5,} 0^{\circ} \mathrm{C}\right)$ with or without thioglycerol in the absence of steroid for various times. $\mathrm{Cy}$ tosol was prepared from livers of four animals, which were divided equally and one set of halves homogenized in 0.05 $M$ Tris and the other half in $0.01 \mathrm{M}$ Tris. (Each cytosol was kept on ice and subaliquots were incubated with steroid after the indicated elapsed time; $\mathrm{A} / \mathrm{J}$ in $0.01 \mathrm{M}$ Tris $\mathrm{O} ; \mathrm{A} / \mathrm{J}$ in $0.05 \mathrm{M}$ Tris $\square$; B10.A in $.01 \mathrm{M}$ Tris $\triangle ; \mathrm{B} 10 . \mathrm{A}$ in 0.05 M Tris $\square$ ). a. Decay of TA binding capacity of cytosol of livers homogenized in buffers without $12 \mathrm{mM}$ thioglycerol (mean \pm S.E. for four determinations). b. Decay of TA binding capacity of cytosol of livers homogenized in buffers with $12 \mathrm{mM}$ thioglycerol (mean \pm S.E. for two to four determinations). Slopes are not significantly different between $A / J$ and B10.A in $0.01 \mathrm{M}$ Tris. 

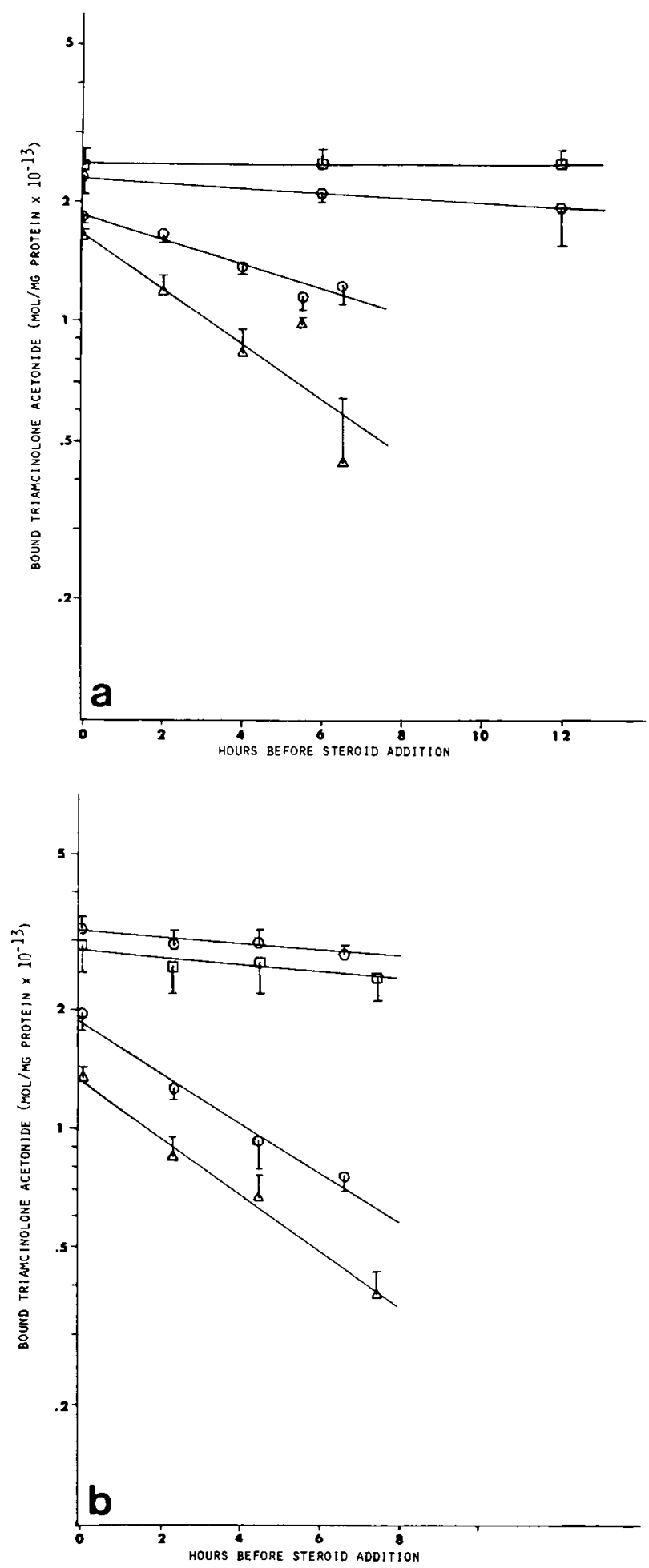
decay curve, subaliquots of chilled $\left(0^{\circ} \mathrm{C}\right)$ cytosol were added to steroid at various times. In both 0.01 and $0.05 \mathrm{M}$ Tris, the receptors of both strains had similar rates of decay. However, the stability in 0.05 was much greater than in $0.01 \mathrm{M}$ Tris: $t^{1 / 2}$ were more than 32 hours and four to ten hours, respectively, in buffers with or without $12 \mathrm{mM}$ thioglycerol (Figs. 3a,b). Thioglycerol did not have a major effect on either stability or receptor levels for either $\mathrm{A} / \mathrm{J}$ or B10.A in either 0.01 or $0.05 \mathrm{M}$ Tris. As in livers homogenized in distilled water, glucocorticoid receptor levels of livers homogenized in buffer are greater in 0.05 than in $0.01 \mathrm{M}$ Tris. In addition, receptor levels of livers homogenized in buffer were generally greater than those of livers homogenized in distilled water before buffer addition at the same Tris concentration.

\section{DISCUSSION}

The data presented herein, and our experiences over the past year using $0.01 \mathrm{M}$ Tris$\mathrm{HCl}, \mathrm{pH} 7.35,12 \mathrm{mM}$ monothioglycerol for a homogenization and incubation media, show convincingly that a strain difference in glucocorticoid receptors can be found more readily in the very low molarity buffer. This conditional strain difference in glucocorticoid receptor levels between the $\mathrm{A} / \mathrm{J}$ and the C57BL (B10.A and C57BL/6J) strains is probably not due to differential decay rates of the glucocorticoid receptor in low molarity buffer since Butley et al. ('78) did not find a significantly different rate of decay between the glucocorticoid receptor levels of $\mathrm{A} / \mathrm{J}$ and $\mathrm{C57BL} / 6 \mathrm{~J}$ nor did we find a significantly different rate of decay between the receptor levels of $\mathrm{A} / \mathrm{J}$ and B10.A, with or without thioglycerol, in $0.01 \mathrm{M}$ Tris. de Pirro et al. ('79) have shown that the glucocorticoid receptor of rat kidney aggregates in distilled water and that a low molarity buffer is unlikely to alter the $\mathrm{pH}$ determined by tissue buffers. It is possible that a similar phenomena accounts for the differential effect of buffer molarity on the strain difference in mouse liver glucocorticoid receptors. Aggregation of the mouse glucocorticoid receptor might also account for the persistence of strain differences when homogenization was performed in distilled water and the homogenate brought to $0.05 \mathrm{M}$ Tris afterwards. There are, however, some contrasts between de Pirro's work and ours. Unlike the rat kidney glucocorticoid receptor, which was more stable in distilled water than in $0.01 \mathrm{M}$ Tris (de Pirro et al., '79), the mouse liver glucocorticoid receptor was much more stable on $0.05 \mathrm{M}$ Tris than in $0.01 \mathrm{M}$ Tris.
In the case of the mouse, this probably reflects a stabilizing effect of the Tris molecule on the glucocorticoid receptor either directly or indirectly on enzymes responsible for its breakdown or inactivation or on other modifiers.

The difference in glucocorticoid receptor stability between rat kidney and mouse liver raises the question of whether or not there are tissue specific glucocorticoid receptors or whether the species difference is paramount. Although multiple molecular forms of glucocorticoid receptors have been described in various tissues (Cochet and Chambay, '76; Koch et al., '76; Sakane and Thompson, '77; Liu and Webb, '78), sometimes even in one laboratory (Agarwal et al., '78), they are probably related to activated and unactivated forms of the receptor, binding of glucocorticoid to contaminating serum proteins such as transcortion, etc. Thus, there is little firm evidence for tissue-specific different glucocorticoid receptors. The differences found between laboratories for the direction of a strain difference in glucocorticoid receptor levels might then be sought for in the conditions, rather than the tissues used. Salomon and Pratt ('76, 79) used intact cultured cells from fetal facial tissues while Butley et al. ('78) and Hackney ('80) used cell-free extracts, from adult liver and fetal heads, respectively. The latter two groups both used $0.01 \mathrm{M}$ Tris buffer, but the experiments differed greatly for the time of incubation of steroid with cytosol: 20 hours in the case of hepatic cytosol (Butley et al., '78) and only four hours in the case of fetal head cytosol (Hackney, ' 80 ). Since the rate at which both potent and weak glucocorticoids achieve binding equilibrium with the receptor at $0^{\circ} \mathrm{C}$ is very slow (Pratt et al., '75), the former condition may be the proper one. Thus, differences in technique and not in age and tissue may explain different findings between fetal and adult receptors.

Evidence is slowly accumulating that reduces the probability that the H-2 has a direct or indirect effect on the differences in glucocorticoid receptor levels between strains of mice. The locus for glucocorticoid receptor, which may be expressed in all relevant tissues, has been identified as being on chromosome 18 in the mouse (Franke and Behring, ' 80 ), whereas the H-2 locus is on a different chromosome, chromosome 17. Thus, the H-2 locus cannot be the glucocorticoid receptor locus. In the strains that we have studied (A/J, A.BY, C57BL/6J, and B10.A), A/J and A.BY have nearly identical genetic backgrounds but have different H-2 haplotypes, $\mathrm{H}-2^{\mathrm{a}}$ and $\mathrm{H} \cdot 2^{\mathrm{b}}$, respectively, while 
$\mathrm{C} 57 \mathrm{BL} / 6 \mathrm{~J}$ and B10.A have nearly identical backgrounds but differ for the H-2 locus; $\mathrm{H}-2^{\mathrm{b}}$ and $\mathrm{H}-2^{\mathrm{a}}$, respectively. Butley et al. ('78) have shown that in these four strains, background and not $\mathrm{H}-2$ haplotype controls hepatic receptor levels. In addition, Leach et al. ('82) have shown that the H-2 complex does not affect the level of endogenous glucocorticoid receptor modifiers. The appearance of a difference in the receptor levels between the C57BL background (B10.A and C57BL/6J) and the A background $(\mathrm{A} / \mathrm{J})$, only under some buffering conditions, also does not appear to be under $\mathrm{H}-2$ haplotype control since C57BL/6J and B10.A have different $\mathrm{H}-2$ haplotypes but show a difference from $\mathrm{A} / \mathrm{J}$ under the same buffering conditions.

Differences among inbred strains of mice for levels of glucocorticoids have been known for some time and $\mathrm{A} / \mathrm{J}$ is a low (Badr and Spickett, '65) and C57BL/10J is a high (Doering et al., '72) strain. Down-regulation of glucocorticoid receptor levels in response to cell surface reagents has been demonstrated (McGinnis and de Vellis, ' 81 ) but has not been shown, to our knowledge, in response to glucocorticoids. Nonetheless, down-regulation of glucocorticoid receptor in response to chronic high levels of glucocorticoid could occur by evolution, if not as a physiological response.

\section{ACKNOWLEDGMENTS}

This work was supported by a grant from the National Foundation-March of Dimes. We thank W. B. Pratt for a gift of $\left[{ }^{3} \mathrm{H}\right]-\mathrm{TA}$ and Mrs. Rena Jones for excellent secretarial assistance.

\section{LITERATURE CITED}

Agarwal, M.K., M. Phillipe, and F. Coupry (1978) Tissue dependent receptor binding of a $9 x$ fluorohydrocortisone. Biochem. Biophys. Res. Commun., 83:1-6.

Arányi, P., and A. Náray (1980) Effect of calcium on chick thymus glucocorticoid receptor. J. Steroid Biochem., 12:267-272.

Badr, F.M., and S.G. Spickett (1965) Genetic variation in the biosynthesis of corticosteroids in Mus musculus. Nature, 205:1088-1090.

Butley, M.S., R.P. Erickson, and W.B. Pratt (1978) Hepatic glucocorticoid receptors and the $\mathrm{H}-2$ locus. Nature, 275:136-138.

Cochet, C., and E.M. Chambay (1976) Glucocorticoid binding in the chicken liver cytosol: Characterization of five macromolecular binding components. Biochim. Biophys. Acta, 444:240-251.

de Pirro, R., C. Milani, A. Fusco, and R. Lauro (1979) Aggregation-induced stability of dexamethasone receptors in rat kidney. Clin. Chim. Acta, 96:9-14.

DiSorbo, D.M., D.S. Phelps, V.S. Ohl, and G. Litwak (1980) Pyridoxine deficiency influences the behaviour of the glucocorticoid receptor complex. J. Biol. Chem., 255:3866-3870.
Doering, C.H., J.G.M. Shire, S. Kessler, and R.B. Clayton (1972) Cholesterol ester concentration and corticosterone production in adrenals of the C57BL/10 and DBA/2 strains in relation to adrenal lipid depeletion. Endocrinology, 90:93-101.

Dolan, K.P., J.J. Diaz-gil, and G. Litwack (1980) Interaction of pyridoxal $5^{\prime}$-phosphate with the liver glucocorticoid receptor-DNA complex. Arch. Biochem. Biophys., 201:476-485.

Francke, U., and U. Gehring (1980) Chromosome assignment of a murine glucocorticoid receptor gene (Grl-1) us ing intraspecies somatic cell hybrids. Cell, 22:657-664.

Fraser, F.C., and T. Fainstat (1951) Production of congenital defects with particular reference to cleft palate. Pediatrics, 8:527-533.

Goldman, A.S., M. Katsumata, S.J. Yaffe, and D.L. Gasser (1977) Palatal cytosol cortisol-binding protein associated with cleft palate susceptibility and $\mathrm{H}-2$ genotype. Nature, 265:643-645.

Hackney, J.F. (1980) A glucocorticoid receptor in fetal mouse: Its relationship to cleft palate formation. Teratology, 21:39-51.

John, J.K., and V.K. Moudgil (1979) Activation of glucocorticoid receptor by ATP. Biochem. Biophys. Res. Commun., 90:1242-1248.

Koch, B., B. Lutz, B. Briaud, and C. Mialhe (1976) Heterogeneity of pituitary glucocorticoid binding: Evidence for a transcortin-like compound. Biochim. Biophys. Acta, 444:497-507.

Leach, K.L., R.P. Erickson, and W.B. Pratt (1982) The endogenous heat-stable glucocorticoid receptor stabilizing factor and the H-2 locus. J. Steroid Biochem., 17:121-123.

Liu, S.-L.H., and T.E. Webb (1978) Heterogeneity and properties of hepatic dexamethasone-binding proteins. Biochem. J., 180:187-193.

McGinnis, J.F., and J. de Vellis (1981) Cell surface modulation of gene expression in brain cells by down regulation of glucocorticoid receptors. Proc. Natl. Acad. Sci. U.S.A., 78:1288-1292.

Mirás, M.E., and R.W. Harrison (1979) Characteristics of glucocorticoid binding to mouse liver cytosol. J. Steroid Biochem., 11:1129-1134.

Nielsen, C.J., J.J. Sando, and W.B. Pratt (1977a) Evidence that phosphorylation inactivates glucocorticoid receptors. Proc. Natl. Acad. Sci. U.S.A., 74:1398-1402.

Nielsen, C.J., J.J. Sando, W.M. Vogel, and W.B. Pratt (1977b) Glucocorticoid receptor inactivation under cell-free conditions. J. Biol. Chem., 252:7568-7578.

O'Brien, J.M., J.W. Thanassi, and J.A. Cidlowski (1980) 5' deoxypyridoxal inhibition of glucocorticoid receptor binding in HeLa $S_{3}$ cells and rat thymocytes. Biochem. Biophys. Res. Commun., 92:155-162.

Pratt, W.B., J.L. Kaine, and D.V. Pratt (1975) The kinetics of glucocorticoid binding to the soluble specific binding protein of mouse fibroblasts. J. Biol. Chem., 250:4584-4591

Sakane, Y., and E.B. Thompson (1977) Characterization of two forms of glucocorticoid hormone-receptor complex separated by DEAE-cellulose column chromatography. Biochem. Biophys. Res. Commun., 77:533-541.

Salomon, D.S., and R.M. Pratt (1976) Glucocorticoid receptors in murine embryonic facial mesenchyme cells. $\mathrm{Na}$ ture, 264:174-177.

Salomon, D.S, and R.M. Pratt (1979) Involvement of glucocorticoids in the development of the secondary palate. Differentiation, 13:141-154.

Sato, B., K. Noma, Y. Nishizawa, K. Nakoa, K. Matsumoto, and Y. Yamamura (1980) Mechanism of activation of steroid receptors: Involvement of low molecular weight in hibitor in activation of androgen, glucocorticoid, and es trogen receptor systems. Endocrinology, 106:1064-1142. 